\title{
The Role of the Polish Interdepartmental Commission for the Maximum Admissible Concentrations and Intensities for Agents Harmful to Health in the Working Environment in the Development of Safe Working Conditions
}

\author{
Skowroń $\mathbf{J}^{1 *}$, Zapór $\mathbf{L}^{2}$ and Miranowicz- \\ Dzierżawska $\mathrm{K}^{2}$ \\ ${ }^{1}$ Department of Chemical, Aerosol and Biological \\ Hazards, Centralny Instytut Ochrony Pracy-Państwowy \\ Instytut Badawczy/Central Institute for Labour \\ Protection-National Research Institute, Warszawa, \\ Poland \\ ${ }^{2}$ Central Institute for Labour Protection-National \\ Research Institute, Warsaw, Poland \\ *Corresponding author: Jolanta Skowroń, \\ Department of Chemical, Aerosol and Biological Hazards, \\ Laboratory of Toxicology, Centralny Instytut Ochrony \\ Pracy-Państwowy Instytut Badawczy/Central Institute \\ for Labour Protection- National Research Institute, \\ Warszawa, Poland
}

Received: April 02, 2021; Accepted: May 13, 2021; Published: May 20, 2021

\section{Introduction}

The history of setting occupational limit values of agents harmful to health occurring in the working environment in Poland begins around 1956. At that time a list containing 14 chemicals, for which the values of hygiene standards were adopted without justification (documentation), was published. The values were at the same level as in the former USSR. In 1959, in the Regulation of the Council of Ministers of 21 August on general sanitary and hygienic conditions in newly built or reconstructed industrial plants (Dziennik Ustaw z 1959 r. Nr 53, poz. 316 \{Journal of Laws 1959 No. 53, item 316\}) a list of hygiene standards for 183 chemicals and 5 dust was published. In 1976, the list of the Maximum Admissible Concentrations (MACNDS) of chemicals and dust counted 212 items in part A, while part $\mathrm{B}$ indicated the Maximum Admissible Intensities value (MAI-NDN) of $90 \mathrm{~dB}$ for noise at workplaces in factory halls, mines and open spaces (Dziennik Ustaw z 1976 r. Nr 13, poz.77 \{Journal of Laws 1976 No. 13, item 77\}). The definitions of the Maximum Admissible Concentrations (MAC-NDS) and Intensities (MAI-NDN) of agents harmful to health in the working environment were introduced for the first time to the Regulation of the Minister of Labour, Wages and Social Affairs of 22 December 1982 (Dziennik Ustaw z 1982 r. Nr 43, poz.287 \{Journal of Laws 1982 No. 43, item 287\}). This regulation defines the system and manner of making changes to the list, the obligations of enterprises in the case of exceeding the MAC and MAI values as well as the methods of measurement. The State Sanitary Inspection was entrusted with monitoring of the compliance with the provisions of the Regulation. The values of the Maximum Admissible Short-Term Concentration (MAC (STEL)-NDSCh) and Maximum Admissible Ceiling Concentration (MAC(C)-NDSP) were introduced by the regulation of the Minister of Labour, Wages and Social Affairs of 27 November 1985 (Dziennik Ustaw z 1985 r. Nr 56, poz.290 \{Journal of Laws 1985 No. 56, item 290\}).

Since 1983, the establishment and verification of the concentration limits for chemicals and admissible intensities (MAI) for physical factors in the working environment has been carried out by the Interdepartmental Commission for the Updating of the MAC and MAI for Agents Harmful to Health in the Working Environment.

The Commission was established by the regulation No. 33 of the Minister of Labour, Wages and Social Affairs and the Minister of Health and Social Care on 27 June 1983.

In 1996, by the Regulation of the Prime Minister of 28 May 1996, the name of the Commission was changed to the "Interdepartmental Commission for Maximum Admissible Concentrations and Intensities of Agents Harmful for Health in the Working Environment" (Dziennik Ustaw z 1996 Nr 61, poz. 284 \{Journal of Laws 1996 No. 61, item 284\}) and 26 members of the Commission were appointed.

The current composition of the Interdepartmental Commission for MAC and MAI is included in the Regulation of the Prime Minister of 15 December 2008 (Dziennik Ustaw z 2008 r. Nr 225, poz.1490 ze zmianami Dziennik Ustaw 2019 poz. 2201 \{Journal of Laws 2008
Austin J Public Health Epidemiol - Volume 8 Issue 2 - 2021

ISSN : 2381-9014 | www.austinpublishing group.com

Skowroń et al. (C) All rights are reserved
Citation: Skowroń J, Zapór L and Miranowicz-Dzierżawska K. The Role of the Polish Interdepartmental Commission for the Maximum Admissible Concentrations and Intensities for Agents Harmful to Health in the Working Environment in the Development of Safe Working Conditions. Austin J Public Health Epidemiol. 2021; 8(2): 1098. 


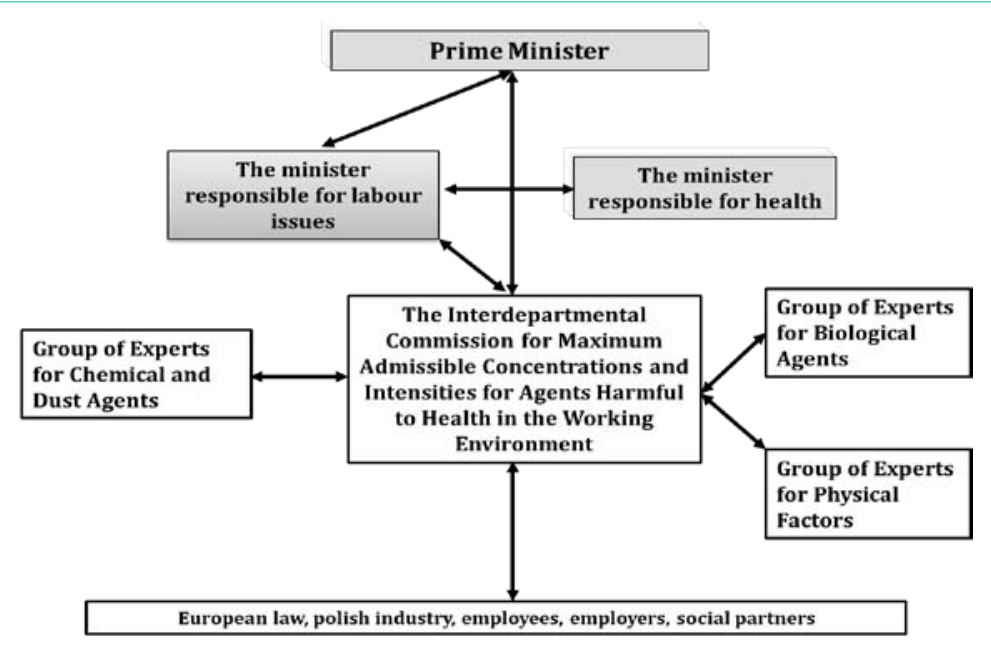

Figure 1: The organization diagram of the Interdepartmental Commission for MAC and MAI in Poland.

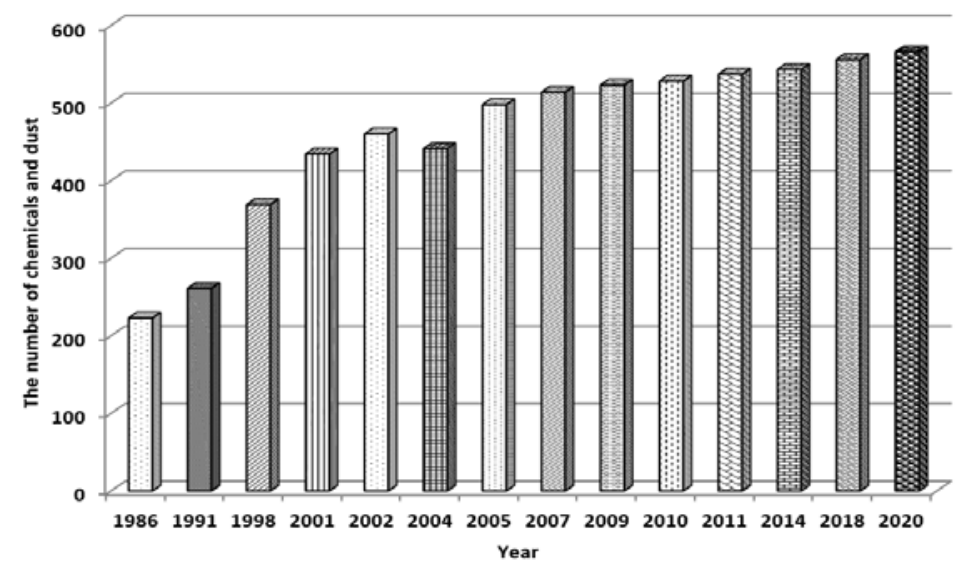

Figure 2: The number of chemicals and dust harmful to health for which the maximum admissible concentrations were established in $1986-2020$.

No. 225, item 1490 as amended Journal of Laws 2019 item 2201\}). Currently, the Commission consists of 32 members. Representatives of the Ministries (of health, labour, industry, environmental protection), scientific institutions and social partners are involved in the work of the Commission (Figure 1).

\section{The Interdepartmental Commission for MAC and MAI in Poland}

The Interdepartmental Commission for MAC and MAI carries out tasks aimed at protecting the health and safety of employees against the risks associated with exposure to chemical and physical factors harmful to health in the working environment. To support this, the continuous expansion and verification of the list of admissible concentrations and intensities levels of hazardous agents in the workplace is essential. The Commission has appointed a Group of Experts for Chemical and Dust Agents, a Group of Experts for Biological Agents and a Group of Experts for Physical Factors. These groups consist of independent experts in the fields of toxicology, occupational medicine and occupational hygiene. They include specialists from the Polish research centres: clinicians, toxicologists, biochemists, microbiologists, epidemiologists, morphologists, chemists, physicists, analysts and occupational physicians. The main responsibilities of the Commission are:

- To consider, evaluate and adopt exposure limits for chemical and physical agents in the working environment.

- To develop, as necessary, expert opinions on the value of the MAC and MAI of agents harmful to health in the working environment.

- $\quad$ To present to the Minister responsible for Labour Issues their own conclusions regarding the values of the MAC and MAI of agents harmful to health in the working environment.

Moreover, the Commission proposes methods of air sampling and analysis, which are standardised by the Polish Committee for Standardisation and, if there are sufficient data, also the biological tolerance limits promulgated by the Minister of Health.

In 1985, the list of the MAC of agents harmful to health included 223 chemicals and dust and one physical factor. Over 37 years of the Commission's activity, the list of MAC values has been extended to more than 343 new chemicals and dust (Figure 2) and the MAI list to 10 physical factors. 


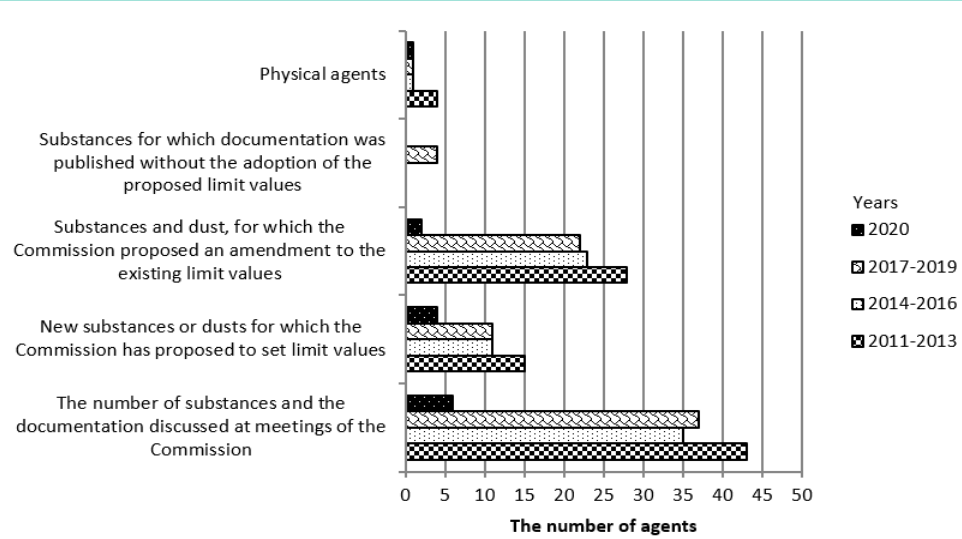

Figure 3: Chemical and physical factors harmful to health occurring in the working environment considered by the Commission between $2011-2020$ (as of October 2020).

The Principles for Establishing Maximum Admissible Concentration and Intensity of Agents Harmful to Health in the Working Environment

According to Article $207 \$ 2$ of the Labour Code, the employer is obliged to protect the health and life of employees by providing safe and hygienic working conditions with appropriate use of the scientific and technical achievements. In accordance with Article 211 of the Labour Code observing the rules and principles of health and safety at work is the primary responsibility of the employee.

The principles of occupational safety and health resulting from the presence of chemical and physical agents harmful to health are associated with the observance of legally binding values of MACs $\{$ MAC (TWA), MAC(STEL) MAC(C)\} and MAI for physical factors determined in a regulation by the Minister responsible for labour issues in agreement with the Minister responsible for health matters.

There are concentration or intensity levels for chemical and physical agents below which no changes will occur to the health of an employee and his future generations, even if they appear in the working environment. According to the type of biological effects, the following categories of MAC values are used:

- NDS-MAC(TWA): MAXIMUM ADMISSIBLE CONCENTRATION: is the time-weighted average concentration for a conventional 8-hour workday and a workweek defined in the Labour Code, to which workers may be exposed during their whole working life (also when retired), without any adverse effects on their health or that of the next generations.

- NDSCh-MAC(STEL): MAXIMUM ADMISSIBLE SHORT-TERM CONCENTRATION: the short-term exposure limit is an average concentration, to which workers may be exposed without any adverse health effects if it does not last longer than 15 minutes and does not occur more than twice during a workday, at intervals not shorter than 1 hour.

- NDSP-MAC(C): MAXIMUM ADMISSIBLE CEILING CONCENTRATION: is the ceiling concentration, which because of the threat to workers' health or life, should not be exceeded even instantaneously.
- NDN-MAI: MAXIMUM ADMISSIBLE INTENSITIES: is the level of exposure appropriate to property of individual physical agent, harmful to health, to which workers may be exposed during their whole working life (also when retired), without any adverse effects on their health or that of the next generations.

The values of the maximum admissible concentrations and intensities of agents harmful to health are determined in two stages: Experts' Groups for Chemical or Physical Agents of the Interdepartmental Commission for MAC and MAI make a substantive evaluation of documentation prepared by individual experts and establish proposals for the values of hygiene standards based on health criteria, health risk assessment and current scientific data. Proposals for MAC and MAI values along with the documentation are presented at the meeting of the Interdepartmental Commission. The Commission adopts resolutions by a simple majority with the participation of at least half of the members of the Commission. In the event of an equal number of votes, the chairman's vote decides.

Then, in the form of a proposal, the values accepted by the Commission are addressed to the Minister responsible for labour issues. After the inter-departmental questionnaire, discussions at the meeting arranged by the Minister for labour issues and approval by the Minister for labour issues in consultation with the Minister responsible for health, the values of the MAC and MAI of agents harmful to health in the working environment are published in the Journal of Laws in the form of a regulation on the maximum admissible concentrations and intensities of agents harmful to health. These are hygiene standards that are legally binding for all branches of the national economy.

In total, 67 meetings of the Interdepartmental Commission on MAC and MAI took place in the years 2000-2020 (by mid-year), at which proposals for acceptable concentrations for 371 chemical substances were discussed (Figure 3).

Based on 66 applications of the Interdepartmental Commission for MAC and MAI submitted to the Minister in charge of labour issues in the years 2000-2020, 12 regulations of the Minister responsible for labour on the maximum admissible concentrations and intensities of factors harmful to health were published. The list of MAC values currently contains 566 chemicals and dust as well 
as the following physical factors: noise, ultrasonic noise, vibrations affecting the human body through upper limbs and vibrations with a general impact on the human body, hot and cold microclimate, optical radiation: \{infrared (non-laser), ultraviolet (non-laser), visible (unlabelled) and laser\} and field and electromagnetic radiation in the frequency range $0 \mathrm{~Hz} \div 300 \mathrm{GHz}[1]$.

\section{Chemical Sulbstances and Dust}

The proposals to establish or verify the hygiene standards for chemicals harmful to health occurring in the workplace are reported by the companies to the Interdepartmental Commission for MAC and MAI and to the Group of Experts. Proposals of exposure limit values and intensities are prepared by the Group of Experts in the form of documentation. The documentation of occupational exposure limits prepared by the experts includes information on identification of the harmful agent, physicochemical properties, occupational exposure, information on the consequences of exposure for humans and animals, toxicokinetic and toxicodynamic data, dependence of the toxic effect on the level of exposure, justification of the proposed normative value, methods of determination in the workplace, periodic examinations and preventive recommendations. When preparing the documentation, the experts use original bibliographic materials obtained from: computer information databases (e.g. TOXLINE, MEDLINE, CHEMICAL ABSTRACTS), documentation prepared in the USA, Germany, Sweden, materials of the World Health Organization (WHO) and the International Agency for Research on Cancer (IARC), documentation of the Scientific Committee on Occupational Exposure Limits (SCOEL) and RAC Committee of the European Union as well as from many journals and unpublished documents [2].

The substantive basis for determining normative values are the results of:

- Epidemiological studies in which the relationship between the size and duration of occupational exposure and its health effects was determined.

- Medical observations of groups exposed to specific factors harmful to health in industrial conditions.

- Tests on laboratory animals [2]

The information collected in the documentation is used to determine:

a) Critical organ-an organ in which the critical concentration (i.e. the concentration causing harmful changes) of a chemical substance is first reached under specified exposure conditions of the population.

b) Critical effect-biological changes during or after the exposure, characterized by a functional disturbance or damage, which may affect the efficiency of the whole organism or cause a decrease in its efficiency or increase sensitivity to other harmful factors.

c) Threshold dose the exposure level (dose) at which no response is observed in given experimental conditions.

d) Exposure limits: NOAEL (C) (the highest dose or concentration at which there is no statistically or biologically significant increase in the frequency or severity of adverse effects compared to the control
Table 1: The uncertainty factors used to derive the MAC value from the NOAEL or LOAEL (Czerczak, 2004).

\begin{tabular}{|c|c|}
\hline A & to 2 \\
\hline B & $\begin{array}{l}\text { a - up to } 10 \text { when using tests performed other way than inhalation } \\
\text { b - up to } 3 \text { in the case of using inhalation tests }\end{array}$ \\
\hline C & to 3 \\
\hline D & to 3 \\
\hline E & to 5 \\
\hline
\end{tabular}

$\mathrm{UF}_{\mathrm{s}}=$ A. B. C. D. E (Czerczak, 2004)

group) or LOAEL (C) (the lowest dose or concentration at which statistically or biologically significant increase in the frequency of occurrence of harmful effects or their severity appears, in relation to the control group) are determined on the basis of the results of epidemiological studies in humans or data from animal testing [2].

The NOAEL or LOAEL values are the basis for calculating the MAC for irritant and systemic substances using appropriate Uncertainty Factors (UFs) taking into account: differences in individual sensitivity (A), interspecies differences and the routes of administration of the substance (B), transition from short-term studies to chronic studies (C), the use of LOAEL values instead of NOAEL (D) and the incompleteness or poor quality of the available toxicity data, or the potential effects of the long-term effects of the substance (E). The numerical values of the uncertainty coefficients are presented in Table 1.

To obtain the MAC/OEL for substances with systemic action, the NOAEC or LOAEC value obtained from inhalation tests should be divided by the uncertainty factor:

NDS $=$ NOAEL or LOAEL/UF ${ }_{S}[3]$

For substances with a high speed of action, which include strong irritants, substances with a very low odour threshold and asphyxiation gases due to oxygen deficiency, the health effects of their action can best be assessed on the basis of the ceiling concentrations (MAC(C), which cannot be exceeded during the working day at any time, using the following formula:

$$
\log N D S P=\log \cdot \frac{N O A E L \operatorname{lub} L O A E L}{E_{S}}+1,6 \cdot \log S_{g}
$$

Where in:

- $\quad \log \mathrm{Sg}-\operatorname{logarithm}$ of the standard geometric deviation of the short-term concentrations (5).

It is not possible to establish safe exposure levels for carcinogens. Health risk assessment using various mathematical models is used to develop the exposure limit value proposal for these substances [3]. In Poland, the Interdepartmental Commission for MAC and MAI has adopted acceptable occupational risk levels for carcinogens/mutagens (between 10-4 to 10-3). It means that the Commission has accepted the possibility of an increase in the number of cases to 1 cancer per 10,000 workers exposed, or 1 cancer per 1000 workers exposed to a carcinogen at a given concentration.

The level of acceptable risk depends mostly on the tolerable social and health priorities. The Group of Experts for Chemical and Dust Agents characterises the risk for substances with a proven carcinogenic/mutagenic effect in scientific terms and gives MAC/ OEL values at different risk levels. The Commission adopts the 
Table 2: Recommended threshold limit values for microorganisms and endotoxins in indoor air proposed by the Expert Group for Biological Agents (Górny et al, 2011).

\begin{tabular}{|l|c|c|}
\hline \multirow{2}{*}{\multicolumn{1}{c|}{ Microbial agent }} & \multicolumn{2}{c|}{ Admissible concentration } \\
\cline { 2 - 3 } & Workplaces contaminated with organic dust & Residential and public utility premises \\
\hline Mesophilic bacteria & $\left.1.0 \times 10^{5} \mathrm{cfu}^{3} \mathrm{~m}^{*}\right)$ & $5.0 \times 10^{3} \mathrm{cfu} / \mathrm{m}^{3}$ \\
\hline Gram-negative bacteria & $2.0 \times 10^{4} \mathrm{cfu} / \mathrm{m}^{3}\left(^{*}\right.$ & $2.0 \times 10^{2} \mathrm{cfu} / \mathrm{m}^{3}$ \\
\hline Thermophilic actinomycetes & $\left.2.0 \times 10^{4} \mathrm{cfu}^{3} / \mathrm{m}^{*}\right)$ & $2.0 \times 10^{2} \mathrm{cfu} / \mathrm{m}^{3}$ \\
\hline Fungi & $\left.5.0 \times 10^{5} \mathrm{cfu}^{3} / \mathrm{m}^{*}\right)$ & $5.0 \times 10^{3} \mathrm{cfu} / \mathrm{m}^{3}$ \\
\hline Agents from the risk group 3 and 4 & $0 \mathrm{cfu} / \mathrm{m}^{3}$ & $0 \mathrm{cfu} / \mathrm{m}^{3}$ \\
\hline Bacterial endotoxin & $200 \mathrm{ng} / \mathrm{m}^{3}\left(2000 \mathrm{EU} / \mathrm{m}^{3}\right)^{(*)}$ & $5 \mathrm{ng} / \mathrm{m}^{3}\left(50 \mathrm{EU} / \mathrm{m}^{3}\right)$ \\
\hline
\end{tabular}

\section{Explanations:}

„cfu” means „colony forming units", i.e., the number of microbial cells, spores or their aggregates that are able to grow on proper agar medium as separate colonies.

${ }^{(*)}$ For the respirable fraction the proposed values should be lowered by a half; EU: Endotoxin Units.

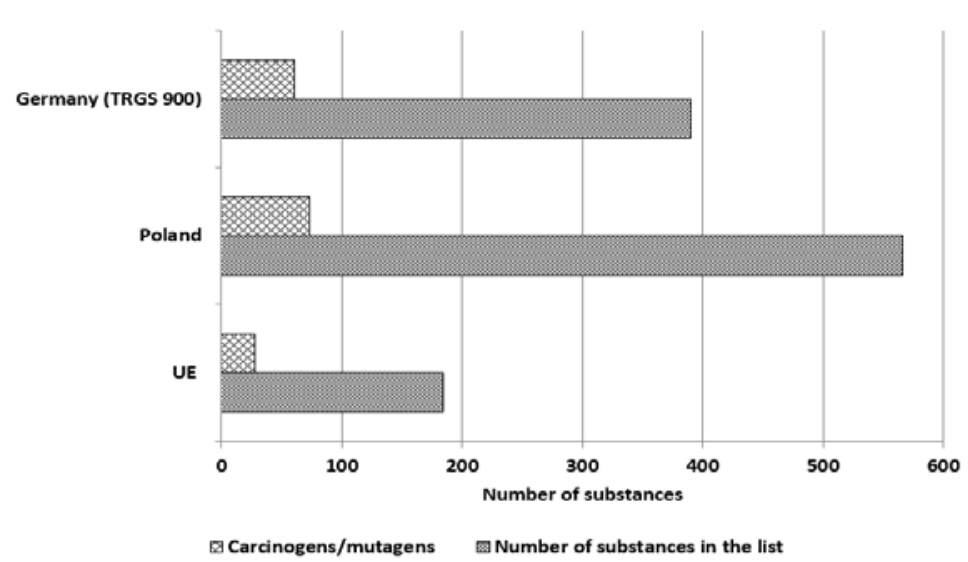

Figure 4: A summary of the number or carcinogenic/mutagenic substances for which the limit values have been established in comparison to the total number of substances included in the appropriate lists in the EU, Germany and Poland.

proposed MAC values at the acceptable risk $[4,5]$. Currently, there are 566 chemicals and dust on the Polish MAC list. The MAC were established for 68 carcinogenic or mutagenic chemicals and dust [1].

Parallel to the process of developing documentation and proposals of MAC(TWA), a separate procedure is launched to develop a method for determining the concentrations of substances at the workplaces. Analytical methods are an integral part of the documentation, because they allow for measurements of chemical concentrations in the air at the workstations. At the workplaces, where employees are exposed to chemicals having the national occupational exposure limits established, the employees should ensure that tests and periodic measurements of these factors are carried out, according to the frequency specified in the Regulation of the Minister of Health of 2 February 2011 on tests and measurements of agents harmful to health in the working environment (Dziennik Ustaw $2011 \mathrm{Nr} 33$, poz.166 ze zmianami \{Journal of Laws of 2011, No 33, item 166 as amended\}).

The documentation of occupational exposure limits, methods for measuring and assessing occupational exposure to specific factors in the working environment and articles are published in the Commission's quarterly 'Principles and Methods of Assessing the Working Environment'. The publication is indexed in the following databases: ARIANTA, BazTech, CISDOC, Chemical Abstracts, Index Copernicus and OSH UPDATE. The first issue of the Commission's quarterly was published in 1985 . Until 2000, the journal appeared non- periodically and came out 2-3 times a year. Since 2000, the "Principles and Methods of Assessing the Working Environment" has been published four times a year. Within 20 years, the documentation for over 346 chemicals and dust as well as 280 methods for determining the concentrations of chemical agents and the intensity level of physical factors in the working environment have been published. On their basis, the draft Polish standards had been developed and then included in the standardisation process as the Polish Standards. Sixty scientific articles have also been published. Knowledge of the data contained in the full documentation regarding the impact of harmful factors on the human body is needed to determine the appropriate medical prevention and to take adequate corrective actions to improve the working conditions. The journal also publishes annual reports on the activities of the Interdepartmental Commission for MAC and MAI [6].

The lists of maximum admissible concentrations and intensities of factors harmful to health in the working environment regulated by the Minister responsible for labour, methods of assessment of occupational exposure to various factors in the working environment, as well as the basic principles of prevention are published in the paper prepared by the Commission: "Harmful agents in the working environment admissible values". This publication also contains a list of the limit values recommended in the biological material (BLV, DSB) for 40 chemicals recommended by the Commission for MAC and MAI [7]. 


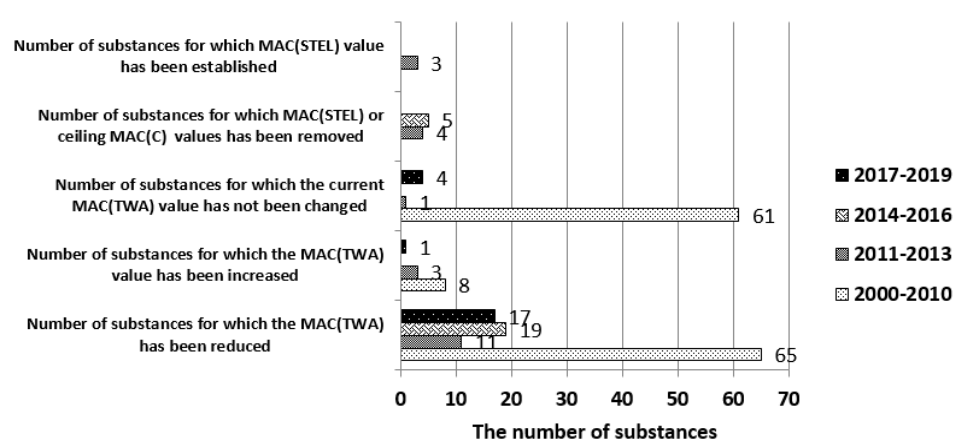

Figure 5: The number of substances for which the current MAC (TWA) or MAC (STEL) values have been reduced, increased or left in force in Poland in $2000-2019$.

Biological monitoring is the measurement of a substance or its metabolites in biological material and the assessment of its biological effect. Concentrations of substances in the air corresponding to BLV and DSB values should not cause adverse changes to the health of persons exposed in the workplace. The toxic substances or their metabolites are determined mainly in the blood, urine and in the exhaled air. The biological monitoring allows for the assessment of exposure to a substance that is absorbed into the body both by inhalation and through the skin [7].

\section{Physical factors}

Physical factors occur only as different types of energy or forces. Therefore, they do not have a "material" form, allowing them to be collected in a controlled environment, stored and further processed in laboratory conditions in their original, quality and quantity. Consequently, the exposure to a physical agent must be quantified directly during its action. Once the exposure is interrupted, only the possible results of this action can be observed in the body, and there is no trace of the factor itself. This indicates the fundamental importance of environmental measurements, which in the case of physical factors must be carried out during the employee's exposure, and so often and in such a time and spatial distribution that the results of the measurement reliably depict the distribution of exposures at different locations of the employee. The dynamics of changes in exposure to the physical factors must also be captured.

In addition to determining the intensity level, it is equally important to define the time of its impact, because the biological effects caused by physical factors are always a function of the dose of a given energy absorbed by the exposed organism. This dose is the product of the factor intensity and the duration of its impact. Moreover, the aggregation of doses over a long period of employment under the exposure to a given factor is also possible.

MAI values for some physical factors, in addition to the average value related to the 8 -hour daily working time, also include the maximum and instantaneous (peak) permissible value of exposure to these factors [7].

\section{Biological factors}

The Group of Experts for Biological Factors of the Interdepartmental Commission for MAC and MAI adopted a definition according to which the harmful biological agents posing an occupational hazard are such micro- and macroorganisms or such structures and substances produced by these organisms that have a harmful effect on human body in the working environment and may be the cause of occupational diseases. In 2004, after analysing the available data, the Group of Experts proposed to adopt recommended values for the concentrations of the most common categories of microorganisms and bacterial endotoxin in the air of both the industrial and the non-industrial working environment (Table 2).

The recommended values for biological factors have also been published in the Commission publication "Harmful Agents in the Working Environment - Admissible Values". These values can be helpful in interpreting the results of measurements of harmful biological agents in the working environment and in taking preventive steps [7].

\section{Adaptation of the Working Conditions in Poland to the Level of the European Union}

The last 20 years of the activity of the Interdepartmental Commission for MAC and MAI may be described as a continuous process of expanding and verifying the list of maximum admissible concentrations and intensities of factors harmful to health in the working environment. It is aimed at adjusting Polish legislation in the field of occupational health and safety to the European Commission (EC) policy. The general principles for ensuring the safety and health of workers at work are contained in Directive 89/391/EEC, known as the Framework Directive [8]. Detailed recommendations regarding the protection of employees from the risks related to exposure to chemicals at work are included in Council Directive 98/24/EC [9], while for specific physical agents - in the relevant specific directives.

\section{Chemicals}

In Europe, since 1995, work on determining Indicative Occupational Exposure Limit Values (IOELV) for chemical agents in the working environment has been carried out by the Scientific Committee on Occupational Exposure Limits to Chemical Agents (SCOEL). The IOELV values determined by the Committee are indicative values for all countries of the European Community. They are determined based on the latest scientific data, taking into account the availability of measuring techniques. They set indicative exposure levels below which no harmful effects of a substance are expected. Determining the IOELV values by SCOEL for substances with a carcinogenic effect depends on the mode (type), mechanism of this action, i.e. whether the substance has a genotoxic effect or not. In addition, the SCOEL sets ceiling values for chemical substances in relation to the 15 minute exposure (STEL) and, if relevant data 
are available, the limit values in the biological material (BLV). In addition, some values are marked with the word "skin", indicating that the substance has been absorbed through the skin. Directives: 91/322/EEC, 98/24/EC, 2000/39/EC, 2006/15/EC, 2009/161/EC, 2017/164/EU and 2019/1831/EU contain lists of indicative values for 158 chemical substances [9-15].

The European Commission has decided that in relation to substances classified as carcinogenic/mutagenic, Binding Occupational Exposure Limit Values (BOELVs) will be established. These values are determined based on the latest scientific data, socioeconomic conditions and the technical possibilities of achieving such value in the industry.

Until 2017, binding values were established at EU level for 3 substances (Directive 98/24/EC - lead and its inorganic compounds, 2004/37/EC - benzene and 2009/148/EC - asbestos) [9,16,17]. Unlike IOELV values, which are implemented in the EU law by the Commission directive, BOELV values are introduced by a decision of the Council and the European Parliament. For substances for which BOELV values have been set, the Member States must establish appropriate national values, which may be at the same level but must not exceed the values set in the EU. The IOELV and BOELV values are necessary for the employer to determine and assess the hazard in accordance with Article 4 of Directive 98/24/EC of 7 April 1998 on the protection of the health and safety of workers from the risks related to chemical agents at work [9]. Directives of the European Parliament and of the Council (EU) 2017/2398, 2019/130 and 2019/983, amending Directive 2004/37/EC on the protection of workers from the risk of exposure to carcinogens and mutagens at work, set binding occupational exposure limits in relation to 28 chemical agents [18-21]. The abovementioned directives have been transposed in Poland into the national law in the Regulation of 12 June 2018 and the Regulation of 9 January 2020 amending the Regulation on the maximum admissible concentrations and intensities of harmful to health agents in the working environment [1]. A summary of the number or carcinogenic/mutagenic substances for which the limit values have been established in comparison to the total number of substances included in the appropriate lists in the EU, Germany [22] and Poland [1], is shown in Figure 4.

Since 2019, the Committee for Risk Assessment (RAC) of the European Chemicals Agency (ECHA) has carried out a scientific evaluation of the relationship between health effects of hazardous chemical substances and occupational exposure levels. The RAC Committee may also make recommendations regarding the notation of "skin" indicating that it must be protected. Other notations, such as "allergy" are also possible. Moreover, the RAC Committee can also set Biological Limit Values (BLV) or Biological Guidance Values (BGV) [23-26].

\section{Physical factors}

For physical factors, EC directives assume the introduction of so-called "Minimum requirements". In this case, the Member States are authorised to maintain or introduce their own stricter provisions than those contained in the directives, provided, however, that they comply with the provisions of the Treaty of Rome signed on 2 October 1997. This is a solution aimed at harmonising the progress achieved, which allows the Member States for a certain degree of freedom in transposing these provisions into the national law.

As regards physical factors, legislative work has been completed to incorporate the provisions of Directive 2002/44/EC (on vibration) and Directive 2003/10/EC (on noise) into the Polish law [1]. The provisions of both above mentioned directives are implemented into the Polish law by one legal act, i.e. by the Regulation of the Minister of Economy and Labour of 5 August 2005 on occupational safety and health for works related with exposure to noise or mechanical vibrations (Dziennik Ustaw z 2005 r. Nr 157, poz. 1318 \{Journal of Laws 2005 No. 157, item 1318\}). This regulation contains occupational health and safety requirements for work that may be accompanied by harmful physical factors in the working environment in the form of noise or mechanical vibrations. The provisions of Directive 2006/25/ EC concerning artificial optical radiation have been implemented into the Polish law by the Regulation of the Minister of Labour and Social Policy of 27 May 2010 on occupational safety and health at work relating to exposure to optical radiation (Dziennik Ustaw $\mathrm{z}$ 2010 r. Nr 100, poz. 643 \{Journal of Laws 2010 No. 100, item 643\}) and the Regulation of the Minister of Labour and Social Policy of 29 July 2010 amending the Regulation on the maximum admissible concentrations and intensities of harmful to health agents in the working environment (Dziennik Ustaw z 2010 r. Nr 141, poz. 950 \{Journal of Laws 2010 No. 141, item 950\}) (23.24).

In 2015, Directive 2013/35/EU of the European Parliament and of the Council of 26 June 2013 on the minimum health and safety requirements regarding the exposure of employees to the risks caused by physical factors (electromagnetic fields) was implemented into the Polish law (the 20th individual Directive within the meaning of Article 16 (1) of Council Directive 89/391/EEC) and repealing Directive 2004/40/EC (Dziennik Urzędowy UE L 179 z 29.6.2013, s.1 \{Official Journal EU L 179 of 29.6.2013, p. 1\}).

\section{Discussion and Summary}

The Polish system for determining the maximum admissible concentrations and intensities of harmful to health agents, which includes documentation and measurement methods, has allowed for relatively quick adaptation of the Polish regulations to the provisions of the European law in the field of occupational health and safety. The members of the Commission cooperate with other global organisations while establishing hygiene standards, including ACGIH or the German MAK Commission.

It appears from the data provided, that the requirements for plants using or producing chemical substances have been tightened or lowered in those cases, which were justified by the state of the art. In a few cases the normative values have not been changed or even increased, so that the competitiveness of the Polish enterprises would not be unnecessarily reduced (Figure 5).

In all cases reported by the industry, representatives of interested companies were also invited to the meetings of the Interdepartmental Commission on MAC and MAI to directly discuss their specific problems. As a rule, these meetings ended with identifying changes that the companies were planning to implement in their programmes for improving working conditions.

In view of the increase in the number of chemicals used, both the Polish list of NDS (566 chemical and dust substances), as well as 
the recommended and binding lists in the European Union countries (Denmark - 650 chemical substances on the list, France - 670, Belgium - 640) and in the USA (ACGIH - 692 listed chemicals) are insufficient for a proper occupational exposure assessment. For this reason, the Interdepartmental Commission for MAC and MAI systematically extends and updates the list of occupational exposure values. The selection of the substances for the development of occupational exposure limit documentation takes into account the work carried out in RAC and the industry's need to develop occupational exposure limit values. In addition, MAC documentation is also prepared for those for which there are inconsistencies between existing MAC (TWA) values and those established in other countries.

The lack of established hygiene standards for certain chemicals in accordance with Article $220 \S 2$ of the Labour Code would require employers to conduct expensive tests in order to determine the extent to which these substance are harmful to the health of employees.

The rapid setting of concentration limits for 50 carcinogens and the development of a European legal act that would harmonise the existing limit values for all exposed EU workers requires extensive consultation. Both employers and unfortunately employees are protesting against reduction of the limit values for carcinogens and mutagens in workplaces at national level, for fear of losing their jobs.

The European Commission plans a further revision of Directive 2004/37/EC on carcinogens and mutagens, which will apply to substances such as: acrylonitrile, benzene and nickel compounds.

\section{Acknowledgement}

This paper has been based on the results of a research task carried out within the scope of the fifth stage of the National Program" Improvement of safety and working conditions " partly supported in 2020-2022 - within the scope of state services - by the Ministry of Family, Labor and Social Policy and by the Ministry of Economic Development, Labor and Technology. The Central Institute for Labor Protection - National Research Institute is the Program's main cocoordinator.

\section{References}

1. PL 2018. Rozporządzenie Ministerstwa Rodziny, Pracy i Polityki Społecznej z dnia 12 czerwca 2018 r. w sprawie najwyższych dopuszczalnych stężeń i natężeń czynników szkodliwych dla zdrowia w środowisku pracy. Dziennik Ustaw z 2018 poz.1286 ze zmianami Dziennik Ustaw 2020, poz. 61, \{Journal of Laws 2018, item 1286 as amended Journal of Laws 2020, item 61). 2018.

2. Skowroń J, Czerczak S. Rules and recent trends for setting health-based occupational exposure limits for chemicals. International Journal of Occupational Medicine and Environmental Health. 2015; 28: 243-252.

3. Czerczak S. Zasady ustalania wartości najwyższych dopuszczalnych stężeń chemicznych czynników szkodliwych w środowisku pracy. PiMOŚP. 2004 4: 5-18.

4. Skowroń J, Czerczak S. Zasady ustalania dopuszczalnych poziomów narażenia dla czynników rakotwórczych w środowisku pracy w Polsce i w krajach Unii Europejskiej [Principles of establishing occupational exposure limits for carcinogens in Poland and in other EU countries]. Med. Pr. 2013; 64: 541-563.

5. Skowroń J. Substancje rakotwórcze w środowisku pracy w świetle ustawodawstwa polskiego i europejskiego [Carcinogens in the workplace in the light of Polish and European legislation]. Inżynieria Ekologiczna [Ecological Engineering]. 2016; 50: 71-81.

6. Koradecka D, Skowroń J. Sprawozdanie z działalności Międzyresortowej
Komisji do spraw Najwyższych Dopuszczalnych Stężeń i Natężeń Czynników Szkodliwych dla Zdrowia w Środowisku Pracy w latach 2017-2019 [The activity of the Interdepartmental Commission for Maximum Admissible Concentrations and Intensities for Agents Harmful to Health in the Working Environment in 2017-2019]. PiMOŚP. 2020; 1:, 5-34.

7. Pośniak M. (eds). Harmful Agents in the Working Environment - Admissible Values. Warsaw: CIOP-PIB (in Polish). 2018.

8. EC [European Commission]. Council Directive 89/391/EEC of 12 June 1989 on the introduction of measures to encourage improvements in the safety and health of workers at work. Official Journal of the European Union. 1989.

9. EC [European Commission]. Council Directive 98/24/EC of 7 April 1998 on the protection of the health and safety of workers from the risks related to chemical agents at work (fourteenth individual Directive within the meaning of Article 16(1) of Directive 89/391/EEC). Official Journal of the European Union. 1998.

10. EC [European Commission]. Commission Directive 91/322/EEC of 29 May 1991 on establishing indicative limit values by implementing Council Directive $80 / 1107 / E E C$ on the protection of workers from the risks related to exposure to chemical, physical and biological agents at work. Official Journal of the European Union. 1991.

11. EC [European Commission]. Commission Directive 2000/39/EC of 8 June 2000 establishing a first list of indicative occupational exposure limit values in implementation of Council Directive 98/24/EC on the protection of the health and safety of workers from the risks related to chemical agents at work. Official Journal of the European Union. 2000

12. EC [European Commission]. Commission Directive 2006/15/EC of 7 February 2006 establishing a second list of indicative occupational exposure limit values in implementation of Council Directive 98/24/EC and amending Directives 91/322/EEC and 2000/39/EC. Official Journal of the European Union. 2006.

13. EC [European Commission]. Commission Directive 2009/161/EU of 17 December 2009 establishing a third list of indicative occupational exposure limit values in implementation of Council Directive 98/24/EC and amending Commission Directive 2000/39/EC. Official Journal of the European Union. $2009 b$.

14. EC [European Commission]. Commission Directive (EU) 2017/164 of 31 January 2017 establishing a fourth list of indicative occupational exposure limit values pursuant to Council Directive 98/24/EC, and amending Commission Directives 91/322/EEC, 2000/39/EC and 2009/161/EU. Official Journal of the European Union. 2017

15. EC [European Commission]. 2019c. Commission Directive (EU) 2019/1831 of 24 October 2019 establishing a fifth list of indicative occupational exposure limit values pursuant to Council Directive 98/24/EC and amending Commission Directive 2000/39/EC. Official Journal of the European Union. 2019c.

16. EC [European Commission]. Directive 2004/37/EC of the European Parliament and of the Council of 29 April 2004 on the protection of workers from the risks related to exposure to carcinogens or mutagens at work (Sixth individual Directive within the meaning of Article 16(1) of Council Directive 89/391/EEC) as amended. Official Journal of the European Union. 2004

17. EC [European Commission]. 2009a. Directive 2009/148/EC of the European Parliament and of the Council of 30 November 2009 on the protection of workers from the risks related to exposure to asbestos at work. Official Journal of the European Union. 2009a.

18. EC [European Commission]. Directive (EU) 2017/2398 of the European Parliament and of the Council of 12 December 2017 amending Directive 2004/37/EC on the protection of workers from the risks related to exposure to carcinogens or mutagens at work. Official Journal of the European Union. Official Journal of the European Union. 2017

19. EC [European Commission]. 2019a. Directive (EU) 2019/130 of the European Parliament and of the Council of 16 January 2019 amending Directive $2004 / 37 / E C$ on the protection of workers from the risks related to exposure to carcinogens or mutagens at work. Official Journal of the European Union. 2019a. 
20. EC [European Commission]. 2019b. Directive (EU) 2019/983 of the European Parliament and of the Council of 5 June 2019 amending Directive 2004/37/EC on the protection of workers from the risks related to exposure to carcinogens or mutagens at work. Official Journal of the European Union. Official Journal of the European Union. 2019b.

21. Skowroń J. Czynniki rakotwórcze i mutagenne w świetle ustawodawstwa polskiego i Unii Europejskiej [Carcinogenic and mutagenic agents in Polish and UE legal regulations]. PiMOŚP [Principles and Methods of Assessing the Working Environment]. 2007; 4: 5-43.

22. DFG. List of MAK and BAT Values 2018: Permanent Senate Commission for the Investigation of Health Hazards of Chemical Compounds in the Work Area. Report 54. 2018

23. ECHA. Joint Task Force ECHA Committee for Risk Assessment (RAC) and Scientific Committee on Occupational Exposure Limits (SCOEL) on Scientific aspects and methodologies related to the exposure of chemicals at the workplace. 2017a.

24. ECHA. Joint Task Force Committee for Risk Assessment (RAC) and Scientific Committee on Occupational Exposure Limits (SCOEL) on Scientific aspects and methodologies related to the exposure of chemicals at the workplace. 2017b.

25. Górny RL, Cyprowski M, Ławniczek-Wałczyk A, Gołofit-Szymczak M, Zapó L. Biohazards in the indoor environment - a role for threshold limit values in exposure assessment. [W:] Dudzińska M.R. (Red.): Management of indoor air quality. Taylor \& Francis Group, London. 2011; 1-20.

26. http://isap.sejm.gov.pl/isap.nsf/download.xsp/WDU20200000061/O/ D20200061.pdf 